\title{
ANALISIS KEPUASAN KONSUMEN TENTANG PELAYANAN PADA DEALER SUZUKI PT. DAS CABANG PANGKALAN BUN
}

\author{
${ }^{1}$ Rinto Alexandro, ${ }^{2}$ Tonich Uda \\ 1,2 Universitas Palangka Raya \\ E-mail: ${ }^{1}$ rinto.alexandro@fkip.upr.ac.id, ${ }^{2}$ tonichuda@fkip.upr.ac.id
}

\begin{abstract}
Every company must have a marketing strategy that can attract consumers' interest, one of them with the services provided. The services provided must be in accordance with the wishes of consumers and even exceed consumer expectations so that the desired goals of the company can be achieved. Furthermore, if the expectations of consumers are met then the satisfaction will be felt by consumers. This will increase trust and consumers will return to use the company's services. In this study using descriptive quantitative research methods. As for the population in this study are customers who use the services of Suzuki Dealer PT. DAS Pangkalan Bun Branch for 1 month and the sample in this study were taken 50 respondents/consumers of PT Suzuki Dealer. DAS Pangkalan Bun Branch. This data was collected through observation, documentation and questionnaires, and analyzed using a percentage formula. Based on the results of data analysis using the percentage formula, it is known that the reliability indicator value is $87 \%$, Responsiveness is $64 \%$, Assurance is $61 \%$, Empathy is $78 \%$ and Tangible is $76 \%$. The highest value on all indicators from the Satisfied column. From the results of this data means consumers are satisfied with the service at the Suzuki Dealer PT. DAS Pangkalan Bun Branch.

Keywords: Consumer Satisfaction, Service
\end{abstract}

\section{ABSTRAK}

Setiap perusahaan harus memiliki strategi pemasaran yang dapat menarik minat konsumen salah satunya dengan jasa pelayanan yang diberikan. Pelayanan jasa yang diberikan harus sesuai dengan keinginan konsumen bahkan melebihi harapan konsumen agar tujuan yang diinginkan oleh perusahaan dapat dicapai. Selanjutnya jika terpenuhi harapan konsumen maka akan munculah kepuasan yang dirasakan konsumen. Hal ini akan meningkatkan kepercayaan dan konsumen akan kembali lagi untuk menggunakan jasa pelayanan perusahaan tersebut. Dalam penelitian ini menggunakan metode penelitian kuantitatif deskriptif. Adapun yang menjadi populasi dalam penelitian ini adalah pelanggan yang menggunakan jasa Dealer Suzuki PT. DAS Cabang Pangkalan Bun selama 1 bulan dan yang menjadi sampel dalam penelitian ini diambil 50 orang responden/konsumen Dealer Suzuki PT. DAS Cabang Pangkalan Bun. Data ini dikumpulkan melalui observasi, dukumentasi dan angket, serta dianalisis dengan menggunakan rumus persentase. Berdasarkan hasil analisis data menggunakan rumus persentase maka diketahui nilai indikator Keandalan (Reliability) sebesar 87\%, Daya Tanggap (Responsiviness) sebesar 64\%, Jaminan (Assurance) sebesar $61 \%$, Empati (Empathy) sebesar 78\% dan Berwujud (Tangible) sebesar 76\%. Nilai tertinggi pada semua indikator dari kolom Puas. Dari hasil data ini artinya Konsumen merasa puas terhadap pelayanan pada Dealer Suzuki PT. DAS Cabang Pangkalan Bun.

Kata Kunci: Kepuasan Konsumen, Pelayanan 


\section{PENDAHULUAN}

Dalam era globalisasi seperti sekarang ini, manajemen suatu perusahaan sangat dituntut kedinamisan, kemampuan dan keberaniannya dalam memunculkan inovasi dan ide baru demi eksistensi perusahaan dan agar tidak jauh tertinggal hingga akhirnya dikalahkan oleh para pesaingnya. Persaingan ini tidak dapat dihindari karena pasti akan terjadi disemua jenis dan bidang usaha. Menurut Malayu. S. P. Hasibuan (2008:1), manajemen hanya merupakan alat untuk mencapai tujuan yang diinginkan. Manajemen yang baik akan memudahkan terwujudnya tujuan perusahaan, karyawan, dan masyarakat. Bagi pengusaha, seluruh aktivitas yang dilakukan mengarah kepada kepastian memperoleh laba. Idiologi pragmatis ini menghendaki variabel biaya produksi ditekan sedemikian rupa agar menghasilkan keuntungan yang paling maksimal. Peraturan perusahaan dibuat sedemikian rupanya sehingga lebih cenderung menguntungkan pengusaha dan para pekerja. Secara umum perusahaan mempunyai tujuan dan sasaran yang sama yaitu keberhasilan dalam mempertahankan hidup, mendapatkan laba dan berkembang. Dalam usaha mencapai tujuan tersebut suatu perusahaan atau usaha harus dapat menggunakan dan mengelola sumberdaya yang tersedia. Dalam hal ini pula perusahaan harus memperhatikan konsumen yang ada. dalam suatu usaha pemasaran dikenal dengan istilah bahwa konsumen (pelanggan) adalah raja. Dalam strategi pemasaran pun yang menjadi pusat perhatian awal adalah konsumen itu sendiri. Dalam hal ini, konsumen harus dipuaskan, karena jika tidak puas maka konsumen akan meninggalkan perusahaan atau usaha tersebut. Konsumen pun akan mencari tempat lain yang bisa memberikan kepuasan tersendiri. Hal ini akan menyebabkan turunnya laba yang dihasilkan dan bahkan bisa menyebabkan kerugian bagi perusahaan tersebut. Oleh karena itu pimpinan atau pemilik modal harus berusaha melakukan pengukuran untuk mengetahui tingkat kepuasan pelanggan dan mengetahui atribut apa dari suatu produknya ( barang atau jasa) yang dapat membuat pelanggan merasa puas. Tingkat kepuasan pelanggan tergantung pada produk barang atau jasa yang ditawarkan. Menurut Philip Kotler (2010:202) mempertahankan dan membesarkan pelanggan adalaha hal yang utama. Perusahaan telah banyak mengeluarkan dana untuk mendapatkan pelanggan yang sekarang ada, dan pesaing selalu merebut mereka. Jadi prinsipnya perusahaan harus memantau tingkat kepuasan pelanggan terhadap produk dan jasa yang sudah ditawarkan pada pihak konsumen. Setiap langkah perusahaan untuk mengembangkan diri dapat dengan mudah ditiru oleh perusahaan lain, sebaliknya sumber daya manusia merupakan sumber keunggulan yang potensial karena kompetensi yang dimilikinya berupa intelektualitas, keterampilan, karakter personal, tidak dapat ditiru oleh perusahaan lain. Menurut Gerson (2004:42) "Mutu pelayanan adalah sasaran untuk mencapai kepuasan dan ikatan. Tujuan bisnis bukan hanya laba, tetapi bagaimana cara memberikan pelayanan yang prima sehingga dapat memberikan kepuasan kepada pelanggan". Dengan demikian kontribusi sumber daya manusia sebagai salah satu faktor pendukung kesuksesan perusahaan sangat disadari oleh para pimpinan puncak dalam suatu perusahaan. Sumber daya manusia merupakan sumber pengetahuan, keterampilan, kemampuan yang terakumulasi dalam diri anggota organisasi yang dalam hal ini adalah perusahaan. Bagi perusahaan yang bergerak dibidang bisnis yang berusaha memenuhi kepuasan pelanggan dengan menyediakan jasa yang berkualitas tinggi demi mendapatkan laba haruslah memperhatikan betul semua faktor yang bisa mempengaruhi pendapat pelanggan. Hal-hal yang menjadi penentu kualitas jasa yaitu Reliability, Responsiveness, Assurance, Empathy, dan Tengible. Dalam perkembangannya dunia bisnis semakin menjamur. Dunia bisnis dewasa ini diwarnai oleh persaingan di berbagai dunia bisnis untuk lebih tanggap pada bidang usaha bisnis yang di inginkan. Pangkalan Bun yang menjadi pusat Kabupaten Kotawaringin Barat pun semakin di imbangi dengan perkembangannya. Hal ini menyebabkan tingkat kesibukan yang tinggi menjadikan perusahaan yang berada dalam bidang perdagangan pun semakin banyak. PT. DAS yang membuka cabang di Pangkalan Bun ingin memberikan pilihan bagi konsumen pada produk yang dijualnya. Pada dealer Suzuki PT. DAS yang berpusat di kota Banjarmasin menawarkan produk yang berbeda merk dari produk yang dijual oleh perusahaan-perusahaan lain yang 
berada pada bidang yang sama. Hal ini menimbulkan persaingan yang kuat antara masingmasing perusahaan. Dealer Suzuki PT. DAS cabang Pangkalan Bun yang berdiri pada tanggal 17 Maret 2003 ini memang sudah cukup berpengalaman dalam sistem pemasarannya. Mereka pun menyadari betapa pentingnya mutu pelayanan selain mutu produk, dan sudah seharusnya memperhatikan kepuasan konsumen dengan memberikan pelayanan yang baik dalam rangka mempertahankan kepercayaan konsumen agar tidak berubah menjadi pelanggan dealer kendaraan roda dua lain. Misalnya dalam hal ketepatan waktu buka, layanan yang cepat kepada pelanggan dalam mengalami keluhan, pengetahuan karyawan tentang produk, perhatian lebih bagi pelanggan, fasilitas yang diberiakan perusahaan dan lain sebagainya. Dalam rangka memasarkan motor bermerek Suzuki ini, maka informasi dan penjelasan-penjelasan yang diketahui agar dapat diberikan kepada konsumen sebagai bahan pertimbangan sehingga konsumen merasa tertarik dan mau membeli produk yang dijual. Oleh sebab itu pelayanan yang baik dan informasi yang jelas dapat mempengaruhi konsumen dalam mengambil keputusan untuk membeli motor di dealer Suzuki PT. DAS. Pelayanan yang baik dan dapat memuaskan konsumen menjadi salah satu faktor penentu keberhasilan dalam pemasaran dan penjualan suatu produk produk barang atau jasa. Dealer merasakan cukup banyak hambatan pada awal-awal menjalankan bisnis yang ada. Dari peralatan terbatas, fasilitas promosi terbatas,pembiayaan kredit awal hanya berasal dari biaya pribadi perusahaan sampai pada SDM yang sedikit. Hal utama yang paling menonjol pun terlihat dari penjualan produk selama satu tahun selama tahun 2012. Pada setiap bulannya, banyak terjadi perbedaan jumlah penjualan produk dari Dealer suzuki ini. Pada bulan januari produk yang terjual 168, februari produk yang terjual 167, maret produk yang terjual 185, april produk yang terjual 166, mei produk yang terjual 147 , juni produk yang terjual 121 , juli produk yang terjual 97 , agustus produk yang terjual 134 , september produk yang terjual 127, oktober produk yang terjual 91 , november produk yang terjual 98 , desember produk yang terjual 155. Jumlah total penjualan pada tahun 2018 adalah 1.656. Dalam penelitian ini permasalahannya, apakah konsumen merasa puas terhadap pelayanan pada Dealer PT. DAS Cabang Pangkalan Bun. Tujuan dari pada penelitian ini untuk menganalisis kepuasan pelanggan tentang pelayanan pada dealer Suzuki PT. DAS cabang Pangkalan Bun. Adapun manfaatnya, pihak pimpinan Dealer Suzuki PT. DAS cabang Pangkalan Bun dalam mengambil keputusan dalam masalah yang dihadapi terutama yang berkenaan dengan peningkatan mutu kualitas pelayanan kepada pelanggan. Serta sebagai acuan pemilik dalam mengambil keputusan kebijaksanaan untuk meningkatkan laba usaha dan penyusunan strategi dalam masa yang akan datang.

\section{LANDASAN TEORI}

Era kompetisi bisnis yang ketat seperti sekarang, kepuasan pelanggan merupakan hal yang utama, pelanggan diibaratkan seorang raja yang harus dilayani namun hal ini bukan berarti menyerahkan segalanya kepada pelanggan. Usaha memuskan kebutuhan pelanggan harus dilakukan secara menguntungkan atau bersifat win-win solution yaitu keadaan dimana kedua belah pihak merasa menang dan tidak ada yang dirugikan. Oleh karena itu di tengah persaingan yang semakin ketat ini diperlukan upaya untuk membina hubungan yang baik antara penyedia jasa dan pelanggan, sehingga terjalinnya kemitraan jangka panjang dengan pelanggan secara terus menerus ini diharapkan dapat menghasilkan bisnis ulangan (repeat business). Dengan upaya ini diharapkan para pelanggan memperoleh kepuasan sesuai harapannya, bersedia membayar dengan harga yang ditetapkan dan mempunyai perasaan komitmen kuat terhadap perusahaan sehingga bersedia untuk menggunakan kembali di masa mendatang. Kepuasan pelanggan adalah konsep penting dalam pemasaran dan penelitian konsumen. Sudah menjadi pendapat umum bahwa jika konsumen merasa puas dengan suatu produk atau merek, mereka cenderung akan terus membeli dan menggunakannya serta memberitahu orang lain tentang pengal aman mereka yang menyenangkan dengan produk tersebut. Jika mereka tidak dipuaskan, mereka cenderung beralih merek serta mengajukan keberatan pada produsen, pengecer, dan bahkan menceritakannya kepada konsumen atau 
pelanggan lain. Hasil kepuasan pelanggan disebut juga dengan mutu, karna mutu dapat didefinisikan sebagai sesuatu yang memuaskan dan melampaui keinginan dan kebutuhan pelanggan. Menurut Fandy Tjiptono (2006:146) Kepuasan konsumen adalah evaluasi secara sadar atau penilaian kognitif menyangkut apakah kinerja produk relatif bagus atau jelek atau apakah produk yang bersangkutan cocok atau tidak cocok dengan pemakaiannya. Engel (M.N. Nasution, 2004:47) mengungkapkan bahwa: Kepuasan konsumen merupakan evaluasi pembeli dimana alternatif yang dipilih sekurang-kurangnya memberikan hasil (outcome) sama atau melampaui harapan pelanggan, sedangkan ketidakpuasan timbul apabila hasil yang di peroleh tidak memenuhi harapan pelanggan. Oliver (dalam Supranto, 2001) mendefinisiskan kepuasan sebagai tingkat perasaan seseorang setelah membandingkan knerja atau hasil yang dirasakannya dengan harapannya. Menurut Philip Kotler dan A. B Susanto (1999:52) kepuasan adalah tingkat perasaan seseorang setelah membandingkan kinerja atau hasil yang dia rasakan dibandingkan dengan harapan. Kepuasan adalah tingkat perasaan seseorang setelah membandingkan kinerja atau hasil yang di rasakan dengan harapannya. Jadi tingkat kepuasan merupakan fungsi dari perbedaan antara kinerja yang dirasakan dengan harapan. Apabila kinerja dibawah harapan, maka pelanggan atau konsumen akan merasa kecewa tetapi sebaliknya apabila kinerja sesuai dengan harapan atau ekspektasi pelanggan, maka pelanggan akan merasa sangat puas. Harapan pelanggan didapat oleh pengalaman masa lalunya, komentar dari kerabatnya serta janji dan informasi pemasar dan saingannya. Pelanggan yang puas akan setia lebih lama, kurang sensitif terhadap harga dan memberikan komentar yang baik tantang perusahaan yang bersangkutan.

Bagi penyedia jasa yang merupakan suatu yang harus dikerjakan dengan baik. Aplikasi kualitas sebagai sifat dari penampilan produk dan kinerja yang merupakan bagian utama dari strategi perusahaan dalam rangka meraih keunggulan yang berkesinambungan, baik sebagai pimpinan pasar ataupun sebagai strategi untuk terus tumbuh. Menurut Sofjan Assauri (1999:205) dalam bukunya manajemen produksi dan operasi, menyatakan kualitas atau mutu diartikan sebagai faktor-faktor yang terdapat dalam barang/hasil yang menyebabkan barang/hasil tersebut sesuai dengan tujuan untuk apa barang/hasil dimaksudkan atau dibutuhkan. Menurut Idris (2009:190) "jasa atau pelayanan" adalah suatu kinerja penampilan, tidak berwujud dan tidak cepat hilang, ia lebih dapat dirasakan dari pada dimiliki. Kondisi suatu jasa/pelayanan yang ditawarkan atau diberikan oleh pengusaha/operator, akan sangat tergantung kepada penilaian pengguna jasa itu sendiri. Pentingnya kualitas pelayanan merupakan hal yang sangat menentukan sekali dalam perkembangan perusahaan, bisnis untuk masa-masa selanjutnya sehingga dengan demikian mendorong mereka selalu berhungan dan melakukan pembelian terhadap barang atau jasa setiap kali mereka membutuhkannya. Dengan kesan-kesan baik ini dapat pula mebuat konsumen-konsumen yang sudah merasakan atau melakukan pembelian dapat menceritakan kepadda orang lain sehingga merupakan promosi gratis bagi perusahaan yang mana dapat meningkatkan pembeli/konsumen baru untuk melakukan pembelian kepada perusahaan. Dengan demikian bukan saja langganan dapat dipertahankan, tapi juga mendapatkan langganan baru yang akan meningkatkan pendapatan perusahaan itu sendiri, lebih-lebih jika pelayanan yang diberikan itu melebihi sifat pelayanan perusahaan pesaing. Menurut Admosudirjo (dalam Tangkilisan: 2004) kualitas pelayanan berarti juga prestasi kerja, prestasi penyelengggaraan sesuatu. Keunggulan produk jasa dan kombinasinya tergantung dari keunikan serta kualitas yangdiperlukan oleh jasa tersebut. Apakah sudah sesuai dengan harapan dan keinginan pelanggan atau konsumen. Kebijakan peningakatan kualitas pelayanan merupakan kebijakan yang digunakan untuk pelayanan dan kualitasnya itu sendiri. Hal ini merupakan bagian dari uapaya perusahaan untuk memperbaiki citra pelayan kepada konsumen. Konsumen harus dilindungi kepentingannya dalam memperoleh produk atau jasa yang dibelinya.maka dari pada itu, perusahaan membutuhkan SDM yang profesional supaya mampu memberikan pelayanan sebagaimana yang diharapkan. Oleh karena itu membutuhkan wahana seperti yang dikemukakan oleh Kirom (2010:28) peran pendidik memegang posisi penting dalam 
mempersiapkan tenaga kerja pelayanan menjadi tenaga kerja yang mampu memberikan pelayanan denga baik, sebagai bentuk pendidikan dan pembelajaran yang berkelanjutan.

Konsumen adalah setiap orang pemakai barang dan/atau jasa yang tersedia dalam masyarakat, baik bagi kepentingan diri sendiri, keluarga, orang lain, maupun makhluk hidup lain dan tidak untuk diperdagangkan. Konsumen adalah orang yang memakai atau mengkonsumsi produk yang di hasilkan atau di jual (Assauri:1987). Biasanya konsumen memiliki motif dalam membeli suatu produk atau barang. Namun setiap konsumen memiliki motif dan perilaku yang berbeda-beda. Motif merupakan alasan dari konsumen mengapa seseorang membeli suatu produk dan apa yang di harapkan atau diinginkan oleh sipembeli atau konsumen produk yang di belinya. Menurut Assauri (1987:123) motif pembelian bagi konsumen di bedakan menjadi 2 yaitu: 1) motif pembelian terhadap produknya (product motives) yang meliputi semua pengaruh serta alasan yang menyebabkan seorang konsumen membeli produk tersebut. 2) motif pembelian terhadap tempat atau penyalur yang menjual produk itu (patronage motives) yang merupakan pertimbangan yang menyebabkan seorang konsumen membeli produk pada tempat penyaluran tertentu. Untuk memahami konsumen dan mengembangkan strategi pemasaran yang tepat kita harus memahami apa yang mereka pikirkan, mereka rasakan, apa yang mereka lakukan, dan apa serta dimana yang mempengaruhi serta dipengaruhi oleh apa yang dipikirkan, dirasakan, dan dilakukan konsumen.

\section{METODOLOGI}

Penelitian ini adalah penelitian jenis kuantitatif. Menurut Sugiyono (2007:8) Penelitian kuantitatif adalah penelitian yang berlandaskan pada filsafat positivisme, digunakna untuk meneliti pada populasi atau sampel tertentu, teknik pengambilan ampel pada umumnya dilakukan secara random, pengumpulan data menggunakan instrumen penelitian, analisis data, bersifat kuantitatif / statistik dengan tujuan untuk menguji hipotesis yang telah di tetapkan. Sedangkan populasinya adalah pelanggan yang menggunakan jasa Dealer suzuki PT. DAS Cabang Pangkalan Bun selama satu bulan pada bulan Mei tahun 2019 sejumlah 98 orang dan sampelnya 50 pelanggan/responden yang berasal atau bertempat tinggal di daerah pangkalan Bun". Karena tidak semua dari pelanggan yang menggunakan jasa Dealer suzuki PT. DAS Cabang Pangkalan Bun yang beralamat di daerah Pangkalan Bun saja. Pengumpulan data menggunakan angket dengan jalan menjaring data persepsi dan penilaian para konsumen mengenai bagaimana kualitas jasa layanan yang diberikan oleh Dealer suzuki PT. DAS Cabang Pangkalan Bun dan kepuasan mereka terhadap kualitas jasa layanan. Metode ini menggunakan daftar pertanyaan yang disebarkan kepada konsumen Dealer suzuki PT. DAS Cabang Pangkalan Bun untuk menggali seberapa jauh tingkat kepuasan konsumen.

Adapun teknik analisis data yang dipergunakan dalam kegiatan penelitian ini adalah menggunakan rumus persentase. Brdasarkan hasil perhitungan diatas maka akan ditarik kesimpulan dari persentase terbanyak yang akan dijadikan sebagai acuan. Data yang telah disusun dikelompokkan, disajikan dan dianalisa dalam bentuk distribusi sederhana. Analisis dilakukan untruk setiap item dengan cara menghitung persentase distribusi frekuensi alternatif jawaban responden. Untukl menghitungnya dicari berdasarkan jumlah frekuensi ang dibagi dengan responden $(n)$ dan dikali dengan $100 \%$ dengan rumus sebagai berikut:

$$
\mathrm{P}=\frac{F}{N} \times 100 \%
$$

$$
\begin{array}{ll}
\text { Keterangan : } \\
\mathrm{P} & =\text { angka persentase } \\
\mathrm{F} & =\text { frekuensi yang sedang dicari persentasinya } \\
\mathrm{N} & =\text { jumlah responden } \\
100 \% & =\text { bilangan pengali tetap (Anas Sujiono, 2008: 43) }
\end{array}
$$


Sedangkan untuk mengetahui kepuasan konsumen terhadap pelayanan Dealer Suzuki PT. DAS cabang Pangkalan Bun, maka pedoman peneliti berpegang pada pendapat ahli yang menyatakan bahwa kriteria ditetapkan sebagai berikut:

$0 \%-20 \% \quad$ Tidak Puas

$20 \%-40 \% \quad$ Kurang Puas

$40 \%-60 \% \quad$ Cukup Puas

$60 \%-80 \% \quad$ Puas

80\%-100\% Sangat Puas. (Ridwan dan Sunarto, 2009:23)

\section{HASIL DAN PEMBAHASAN}

Berdasarkan hasil pengamatan melalui angket (kuesioner) yang di peroleh dari konsumen Dealer Suzuki PT. DAS Cabang Pangkalan Bun dapat di ketahui karakteristik konsumen adalah dari jenis kelaminnya, pekerjaan dan lama menjadi konsumen. Untuk lebih jelasnya lagi maka dapat dilihat dari tabel berikut ini.

Tabel 1. Jenis kelamin responden

\begin{tabular}{ccccc}
\hline No & & Jenis kelamin & Jumlah & Persentase (\%) \\
\hline 1 & Laki-laki & & 38 & 76 \\
2 & Perempuan & 12 & 24 \\
\hline \multicolumn{2}{r}{} & Jumlah & $\mathbf{5 0}$ & $\mathbf{1 0 0}$ \\
\hline
\end{tabular}

Dari tabel di atas terlihat bahwa jenis kelamin responden pada Dealer Suzuki PT. DAS Cabang Pangkalan Bun adalah laki-laki sebanyak 38 orang (76\%) dan perempuan sebanyak 12 orang $(24 \%)$.

Tabel 2. Jenis pekerjaan responden

\begin{tabular}{clccc}
\hline No & & Pekrjaan & Jumlah & Persentase (\%) \\
\hline 1 & PNS & 29 & 58 \\
2 & Karyawan swasta & 14 & 28 \\
3 & Wiraswasta & 7 & 14 \\
\hline \multicolumn{2}{r}{ Jumlah } & $\mathbf{5 0}$ & $\mathbf{1 0 0}$ \\
\hline
\end{tabular}

Dari tabel di atas terlihat bahwa jenis pekerjaan responden pada Dealer Suzuki PT. DAS Cabang Pangkalan Bun adalah konsumen bekerja sebagai PNS sangat mendominasi yaitu sebesar 29 orang (58\%), Karyawan Swasta 14 orang (28\%), dan Wirasawata sebanyak 7 orang (14\%).

Tabel 3. Lama Responden menjadi Pelanggan

\begin{tabular}{|c|c|c|c|}
\hline No & Pekerjaan & Jumlah & Persentase (\%) \\
\hline 1 & $<1$ Tahun & 13 & 26 \\
\hline 2 & $\geq 1$ Tahun & 37 & 74 \\
\hline & Jumlah & 50 & 100 \\
\hline
\end{tabular}

Dari tabel di atas terlihat bahwa responden yang menjadi konsumen pada Dealer Suzuki PT. DAS Cabang Pangkalan Bun adalah lebih banyak konsumen lebih dari atau sama dengan 1 tahun yaitu sebesar 37 orang (74\%) dan kurang dari 1 tahun sebanyak 13 orang (26\%).

\section{Data Hasil Angket}

Angket ini disebarkan kepada 50 responden acak:

\section{Keandalan (Reliability)}

Keandalan (Reliability) menunjukkan kemampuan perusahaan untuk memberikan pelayanan segera, akurat dan memuaskan. Penelitian ini menggunakan 2 item kuesioner Keandalan (Reliability) untuk mengukur persepsi konsumen mengenai kehandalan kualaitas jasa layanan yang ada di Dealer Suzuki PT. DAS Cabang Pangkalan Bun. Pada item 
pertanyaan 1 yaitu ketepatan waktu buka Dealer Suzuki PT. DAS Cabang Pangkalan Bun. Pada item pertanyaaan 2 yaitu sopan santun karyawan. Untuk menilai tanggapan konsumen atas jasa layanan indikator keandalan (reliability), maka hasil persentase dari masing-masing item pertanyaan adalah sebagai berikut:

Tabel 4. Kepuasan Konsumen terhadap ketepatan waktu buka Dealer Suzuki PT. DAS Cabang Pangkalan Bun

\begin{tabular}{clcc}
\hline No & \multicolumn{1}{c}{ Jawaban } & Frekuensi & Persentase \\
\hline 1 & Sangat Puas & - & - \\
2 & Puas & 41 & 82 \\
3 & Cukup Puas & 9 & 18 \\
4 & Kurang Puas & - & - \\
5 & Tidak Puas & - & - \\
\hline \multicolumn{2}{r}{ Jumlah } & 50 & 100 \\
\hline
\end{tabular}

Dari tabel di atas diketahui bahwa penyebaran angket kepada 50 responden tentang item pertanyaan 1 ternyata dari 50 orang tersebut 41 orang (82\%) menyatakan puas, 9 orang (18\%) menyatakan cukup puas. Dari data di atas dapat disimpulkan bahwa sebagaian besar responden memilih jawaban "Puas" yakni sebanyak 41 orang $(82 \%)$ terhadap ketepatan waktu buka Dealer Suzuki PT. DAS Cabang Pangkalan Bun.

Tabel 5. Kepuasan Konsumen terhadap sopan santun karyawan Dealer Suzuki PT. DAS Cabang Pangkalan Bun.

\begin{tabular}{clcc}
\hline No & \multicolumn{1}{c}{ Jawaban } & Frekuensi & Persentase \\
\hline 1 & Sangat Puas & 4 & 8 \\
2 & Puas & 46 & 92 \\
3 & Cukup Puas & - & - \\
4 & Kurang Puas & - & - \\
5 & Tidak Puas & - & - \\
\hline & Jumlah & 50 & 100 \\
\hline
\end{tabular}

Dari tabel di atas diketahui bahwa penyebaran angket kepada 50 responden tentang item pertanyaan 2 ternyata dari 50 orang tersebut 4 orang (8\%) menyatakan sangat puas, 46 orang $(92 \%)$ menyatakan puas. Dari data di atas dapat disimpulkan bahwa sebagaian besar responden memilih jawaban "Puas" yakni sebanyak 46 orang (92\%) kepuasan konsumen terhadap sopan santun karyawan Dealer Suzuki PT. DAS Cabang Pangkalan Bun. Untuk melihat persentase keseluruhan pada item 1 dan 2 pada indikator Reliability dapat dilihat pada tabel berikut.

Tabel 6. Keandalan (Reliability)

\begin{tabular}{cccccc}
\hline \multirow{2}{*}{ Item } & \multicolumn{5}{c}{ Kesimpulan } \\
\cline { 2 - 5 } & Sangat Puas & Puas & $\begin{array}{c}\text { Cukup } \\
\text { Puas }\end{array}$ & $\begin{array}{c}\text { Kurang } \\
\text { Puas }\end{array}$ & $\begin{array}{c}\text { Tidak } \\
\text { Puas }\end{array}$ \\
\hline Ketepanan waktu buka & $8 \%$ & $82 \%$ & $18 \%$ & \\
Sopan santun karyawan & $8 \%$ & $92 \%$ & & \\
\hline Jumlah & $\mathbf{4 \%}$ & $\mathbf{8 7 \%}$ & $\mathbf{9 \%}$ & \\
\hline
\end{tabular}

\section{Daya Tanggap (Responsiviness)}

Daya Tanggap (responsiviness) adalah pemberian pelayanan kepada konsumen secara tanggap dan cepat. Penelitian ini menggunakan 2 item kuesioner daya tanggap (responsiviness) untuk mengukur persepsi konsumen mengenai pelayanan tepat waktu dan ketanggapan karyawan Dealer Suzuki PT. DAS Cabang Pangkalan Bun terhadap konsumen. Pada item pertanyaan 3 yaitu kesiapan karyawan Dealer Suzuki PT. DAS Cabang Pangkalan Bun untuk menanggapi permintaan permintaan konsumen. Pada item pertanyaan 4 yaitu 
pelayanan karyawan yang Dealer Suzuki PT. DAS Cabang Pangkalan Bun yang cepat dalam menangani keluhan. Untuk menilai tanggapan konsumen atas jasa layanan indikator daya tanggap (responsiviness), maka hasil persentase dari masing-masing item pertanyaan adalah sebagai berikut:

Tabel 7. Kepuasan konsumen terhadap kesiapan karyawan Dealer Suzuki PT. DAS Cabang Pangkalan Bun untuk menanggapi permintaan konsumen.

\begin{tabular}{clcc}
\hline No & \multicolumn{1}{c}{ Jawaban } & Frekuensi & Persentase \\
\hline 1 & Sangat Puas & 11 & 22 \\
2 & Puas & 38 & 76 \\
3 & Cukup Puas & 1 & 2 \\
4 & Kurang Puas & - & - \\
5 & Tidak Puas & - & - \\
\hline & Jumlah & 50 & 100 \\
\hline
\end{tabular}

Dari tabel di atas diketahui bahwa peneyabaran angket kepada 50 responden tentang item pertanyaan 4 ternyata dari 50 orang tersebut 11 orang $(22 \%)$ menyatakan sangat puas, 38 orang (76\%) menyatakan puas dan 1 orang (2\%) meyatakan cukup puas. Dari data di atas dapat disimpulkan bahwa sebagaian besar responden memilih jawaban "Puas" yakni sebanyak 38 orang (76\%) terhadap kesiapan karyawan Dealer Suzuki PT. DAS Cabang Pangkalan Bun dalam menanggapi permintaan konsumen.

Tabel 8. Kepuasan konsumen terhadap pelayanan karyawan yang Dealer Suzuki PT. DAS Cabang Pangkalan Bun yang cepat dalam menangani keluhan

\begin{tabular}{clcc}
\hline No & \multicolumn{1}{c}{ Jawaban } & Frekuensi & Persentase \\
\hline 1 & Sangat Puas & 21 & 42 \\
2 & Puas & 26 & 52 \\
3 & Cukup Puas & 3 & 6 \\
4 & Kurang Puas & - & - \\
5 & Tidak Puas & - & - \\
\hline & Jumlah & 50 & 100 \\
\hline
\end{tabular}

Dari tabel di atas diketahui bahwa penyabaran angket kepada 50 responden tentang item pertanyaan 5 ternyata dari 50 orang tersebut 21 orang $422 \%$ ) menyatakan sangat puas, 26 orang (52\%) menyatakan puas dan 3 orang $(6 \%)$ meyatakan cukup puas. Dari data di atas dapat disimpulkan bahwa sebagaian besar responden memilih jawaban "Puas" yakni sebanyak 26 orang (52\%) terhadap pelayanan karyawan Dealer Suzuki PT. DAS Cabang Pangkalan Bun yang cepat dalam menanggapi keluhan. Untuk melihat persentase keseluruhan pada item 3 dan 4 pada indikator Responsiviness dapat dilihat pada tabel berikut.

Tabel 9. Daya Tanggap (Responsiviness)

\begin{tabular}{lccccc}
\hline \multicolumn{1}{c}{ Item } & \multicolumn{4}{c}{ Kesimpulan } \\
\cline { 2 - 5 } & $\begin{array}{c}\text { Sangat } \\
\text { Puas }\end{array}$ & Puas & $\begin{array}{c}\text { Cukup } \\
\text { Puas }\end{array}$ & $\begin{array}{c}\text { Kurang } \\
\text { Puas }\end{array}$ & $\begin{array}{c}\text { Tidak } \\
\text { Puas }\end{array}$ \\
\hline $\begin{array}{l}\text { Kesiapan karyawan untuk } \\
\text { menanggapi permintaan } \\
\text { permintaan konsumen }\end{array}$ & $22 \%$ & $76 \%$ & $2 \%$ & \\
$\begin{array}{l}\text { Pelayanan karyawan dalam } \\
\text { menangani keluhan }\end{array}$ & $42 \%$ & $52 \%$ & $6 \%$ & \\
\hline \multicolumn{1}{c}{ Jumlah } & $32 \%$ & $64 \%$ & $4 \%$ & \\
\hline
\end{tabular}




\section{Jaminan (Assurance)}

Jaminan (Assurance) menujukan pengetahuan, kesopanan, dan sifat dapat dipercaya yang dimiliki oleh para pemberi jasa. Penelitian ini mengguanakan 2 item kuesioner Jaminan (Assurance) untuk mengukur persepsi konsumen mengenai jaminan yang diberikan oleh Dealer Suzuki PT. DAS Cabang Pangkalan Bun kepada konsumennya. Pada item pertanyaan 5 yaitu karyawan Dealer Suzuki PT. DAS Cabang Pangkalan Bun mempunyai pengetahuan dan kemampuan dalam menjalankan tugasnya. Pada item pertanyaan 6 yaitu konsumen merasa puas dengan komunikasi yang efektif antara karyawan kepada konsumen Dealer Suzuki PT. DAS Cabang Pangkalan Bun. Untuk menilai tanggapan konsumen atas kualitas jasa layanan indikator Jaminan (Assurance), maka hasil persentase dari masing-masing item pertanyaan adalah sebagai berikut:

Tabel 10. Kepuasan konsumen terhadap pelayanan karyawan Dealer Suzuki PT. DAS Cabang Pangkalan Bun yang mempunyai pengetahuan dan kemampuan menjalankan tugasnya

\begin{tabular}{clcc}
\hline No & \multicolumn{1}{c}{ Jawaban } & Frekuensi & Persentase \\
\hline 1 & Sangat Puas & 16 & 32 \\
2 & Puas & 29 & 58 \\
3 & Cukup puas & 5 & 10 \\
4 & Kuang Puas & - & - \\
5 & Tidak Puas & - & - \\
\hline & Jumlah & 50 & 100 \\
\hline
\end{tabular}

Dari tabel di atas diketahui bahwa penyebaran angket kepada 50 responden tentang item pertanyaan 5 ternyata dari 50 orang tersebut 16 orang (32\%) menyatakan sangat puas, 29 orang (58\%) menyatakan puas dan 5 orang (10\%) menyatakan cukup puas.. Dari data di atas dapat disimpulkan bahwa sebagaian besar responden memilih jawaban "Puas" yakni sebanyak 29 orang (58\%) terhadap pelayanan karyawan Dealer Suzuki PT. DAS Cabang Pangkalan Bun yang mempunyai pengetahuan dan kemampuan menjalankan tugasnya.

Tabel 11. Konsumen merasa puas dengan komunikasi yang efektif antara karyawan kepada konsumen Dealer Suzuki PT. DAS Cabang Pangkalan Bun

\begin{tabular}{clcc}
\hline No & \multicolumn{1}{c}{ Jawaban } & Frekuensi & Persentase \\
\hline 1 & Sangat Puas & 13 & 26 \\
2 & Puas & 32 & 64 \\
3 & Cukup Puas & 5 & 10 \\
4 & Kurang Puas & - & - \\
5 & Tidak Puas & - & - \\
\hline & Jumlah & 50 & 100 \\
\hline
\end{tabular}

Dari tabel di atas diketahui bahwa penyebaran angket kepada 50 responden tentang item pertanyaan 6 ternyata dari 50 orang tersebut 13 orang (26\%) menyatakan sangat puas, 32 orang (64\%) menyatakan puas dan 5 orang (10\%) menyatakan cukup puas. Dari data di atas dapat disimpulkan bahwa sebagaian besar responden memilih jawaban "Puas" yakni sebanyak 29 orang (58\%) terhadap komunikasi yang efektif antara karyawan kepada konsumen Dealer Suzuki PT. DAS Cabang Pangkalan Bun. Untuk melihat persentase keseluruhan pada item 5 dan 6 pada indikator Assurance dapat dilihat pada tabel berikut. 
Oikos: Jurnal Kajian Pendidikan Ekonomi dan IImu Ekonomi, ISSN Online: 2549-2284

Volume IV Nomor 2, Juli 2020

Tabel 12. Jaminan (Assurance)

\begin{tabular}{|c|c|c|c|c|c|}
\hline \multirow[b]{2}{*}{ Item } & \multicolumn{5}{|c|}{ Keterangan } \\
\hline & $\begin{array}{c}\text { Sangat } \\
\text { Puas }\end{array}$ & Puas & $\begin{array}{c}\text { Cukup } \\
\text { Puas }\end{array}$ & $\begin{array}{c}\text { Kurang } \\
\text { Puas }\end{array}$ & $\begin{array}{l}\text { Tidak } \\
\text { Puas }\end{array}$ \\
\hline $\begin{array}{l}\text { Karyawan mempunyai } \\
\text { pengetahuan dan kemampuan } \\
\text { dalam menjalankan tugasnya. }\end{array}$ & $32 \%$ & $58 \%$ & $10 \%$ & & \\
\hline $\begin{array}{l}\text { Komunikasi yang efektif antara } \\
\text { karyawan kepada konsumen }\end{array}$ & $26 \%$ & $64 \%$ & $10 \%$ & & \\
\hline Jumlah & $29 \%$ & $61 \%$ & $10 \%$ & & \\
\hline
\end{tabular}

\section{Empati (Empathy)}

Empati (empathy) menunjukan peryataan tentang kepedulian dan perhatian kepada konsumen secara individual. Penelitian ini mengguanakan 2 item Empati (empathy) kuesioner untuk mengukur persepsi konsumen mengenai perhatian yang diberikan oleh Dealer Suzuki PT. DAS Cabang Pangkalan Bun kepada konsumennya. Pada item pertanyaan 7 yaitu Dealer Suzuki PT. DAS Cabang Pangkalan Bun memberikan perhatian kepada konsumen secara individual. Pada item pertanyaan 8 yaitu Dealer Suzuki PT. DAS Cabang Pangkalan Bun memberikan perhatian terhadap kebutuhan dan keperluan konsumen. Untuk menilai tanggapan konsumen atas jasa layanan indikator Empati (empathy), maka hasil persentase masing-masing item pertanyaan adalah sebagai berikut:

Tabel 13. Kepuasan konsumen terhadap Dealer Suzuki

PT. DAS Cabang Pangkalan Bun atas perhatian kepada konsumen secara individual

\begin{tabular}{clcc}
\hline No & \multicolumn{1}{c}{ Jawaban } & Frekuensi & Persentase \\
\hline 1 & Sangat Puas & 8 & 16 \\
2 & Puas & 42 & 84 \\
3 & Cukup Puas & - & - \\
4 & Kurang Puas & - & - \\
5 & Tidak Puas & - & - \\
\hline & Jumlah & 50 & 100 \\
\hline
\end{tabular}

Dari tabel di atas diketahui bahwa penyebaran angket kepada 50 responden tentang item pertanyaan 7 ternyata dari 50 orang tersebut 8 orang (16\%) menyatakan sangat puas dan 42 orang $(84 \%)$ menyatakan puas. Dari data di atas dapat disimpulkan bahwa sebagaian besar responden memilih jawaban "Puas" yakni sebanyak 29 orang (58\%) terhadap Dealer Suzuki PT. DAS Cabang Pangkalan Bun atas perhatian kepada konsumen secara idividual.

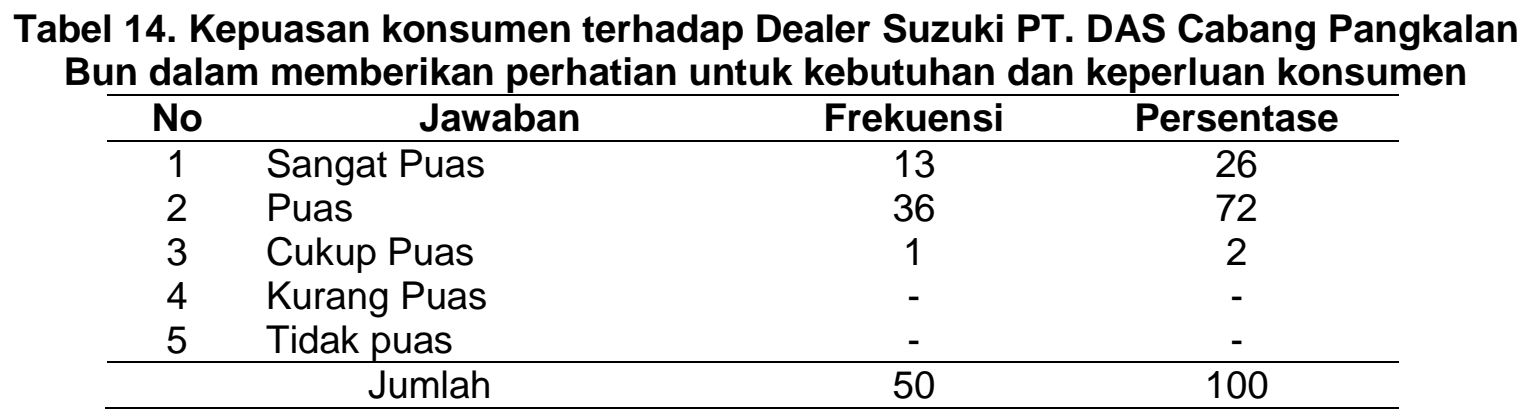

Dari tabel di atas diketahui bahwa penyebaran angket kepada 50 responden tentang item pertanyaan 8 ternyata dari 50 orang tersebut 13 orang (26\%) menyatakan sangat puas, 36 orang $(72 \%)$ menyatakan puas dan 1 orang (2\%) menyatakan cukup puas. Dari data di atas dapat disimpulkan bahwa sebagaian besar responden memilih jawaban "Puas" yakni sebanyak 36 orang (72\%) terhadap Dealer Suzuki PT. DAS Cabang Pangkalan Bun dalam 
Oikos: Jurnal Kajian Pendidikan Ekonomi dan IImu Ekonomi, ISSN Online: 2549-2284

Volume IV Nomor 2, Juli 2020

memberikan perhatian untuk kebutuhan dan keperluan konsumen. Untuk melihat persentase keseluruhan pada item 7 dan 8 pada indikator Empathy dapat dilihat pada tabel berikut:

Tabel 15. Empati (Empathy)

\begin{tabular}{cccccc}
\hline \multicolumn{1}{c}{ Item } & \multicolumn{4}{c}{ Keterangan } \\
\cline { 2 - 6 } & $\begin{array}{c}\text { Sangat } \\
\text { Puas }\end{array}$ & Puas & $\begin{array}{c}\text { Cukup } \\
\text { Puas }\end{array}$ & $\begin{array}{c}\text { Kurang } \\
\text { Puas }\end{array}$ & $\begin{array}{c}\text { Tidak } \\
\text { Puas }\end{array}$ \\
\hline $\begin{array}{l}\text { Memberikan perhatian kepada } \\
\text { konsumen secara individual } \\
\text { memberikan perhatian }\end{array}$ & $16 \%$ & $84 \%$ & & \\
$\begin{array}{l}\text { terhadap kebutuhan dan } \\
\text { keperluan konsumen }\end{array}$ & $26 \%$ & $72 \%$ & $2 \%$ & \\
\hline \multicolumn{1}{c}{ Jumlah } & $\mathbf{2 1 \%}$ & $\mathbf{7 8 \%}$ & $\mathbf{1 \%}$ & \\
\hline
\end{tabular}

\section{Berwujud (Tangible)}

Berwujud (tangible) menunjukan kemampuan Dealer Suzuki PT. DAS Cabang Pangkalan Bun dalam menujukan eksistensinya kepada pihak eksternal. Kondisi fasilitas fisik dan penampilan karyawan adalah merupakan bentuk dari bukti nyata dari kemungkinan akan tingginya kualitas jasa layanan yang diberikan perusahaan. Penelitian ini menggunakn 2 item kuesioner mengenai Berwujud (tangible) dari Dealer Suzuki PT. DAS Cabang Pangkalan Bun. Pada item pertanyaan 9 yaitu kebersihan dan kerapian tempat operasional Dealer Suzuki PT. DAS Cabang Pangkalan Bun. Pada item pertanyaan 10 yaitu penampilan karyawan Dealer Suzuki PT. DAS Cabang Pangkalan Bun rapi dan profesional. Untuk menilai tanggapan konsumen atas kualitas jasa layanan indikator Berwujud (tangible), maka hasil persentase dari masing-masing item pertanyaan adalah sebagai berikut:

Tabel 16. Kepuasan konsumen terhadap kebersihan dan kerapian tempat operasional Dealer Suzuki PT. DAS Cabang Pangkalan Bun

\begin{tabular}{clcc}
\hline No & \multicolumn{1}{c}{ Jawaban } & Frekuensi & Persentase \\
\hline 1 & Sangat Puas & 6 & 12 \\
2 & Puas & 39 & 78 \\
3 & Cukup Puas & 5 & 10 \\
4 & Kurang Puas & - & - \\
5 & Tidak Puas & - & - \\
\hline & Jumlah & 50 & 100 \\
\hline
\end{tabular}

Dari tabel di atas diketahui bahwa penyebaran angket kepada 50 responden tentang item pertanyaan 9 ternyata dari 50 orang tersebut 6 orang $(12 \%)$ menyatakan sangat puas, 39 orang $(78 \%)$ menyatakan puas dan 5 orang $(10 \%)$ menyatakan cukup puas. Dari data di atas dapat disimpulkan bahwa sebagaian besar responden memilih jawaban "Puas" yakni sebanyak 39 orang (78\%) terhadap kebersihan dan kerapian tempat operasional Dealer Suzuki PT. DAS Cabang Pangkalan Bun.

\begin{tabular}{|c|c|c|c|}
\hline No & Jawaban & Frekuensi & Persentase \\
\hline 1 & Sangat Setuju & 13 & 26 \\
\hline 2 & Setuju & 37 & 74 \\
\hline 3 & Kurang setuju & - & - \\
\hline 4 & Tidak setuju & - & - \\
\hline 5 & Sangat tidak setuju & - & - \\
\hline & Jumlah & 50 & 100 \\
\hline
\end{tabular}


Dari tabel di atas diketahui bahwa penyebaran angket kepada 50 responden tentang item pertanyaan 10 ternyata dari 50 orang tersebut 13 orang $(26 \%)$ menyatakan sangat puas dan 37 orang (74\%) menyatakan puas. Dari data di atas dapat disimpulkan bahwa sebagaian besar responden memilih jawaban "Puas" yakni sebanyak 37 orang (74\%) terhadap Penampilan Karyawan Dealer Suzuki PT. DAS Cabang Pangkalan Bun rapi dan profesional. Untuk melihat persentase keseluruhan pada item 9 dan 10 pada indikator Tengible dapat dilihat pada tabel berikut

Tabel 18. Berwujud (Tangible)

\begin{tabular}{lccccc}
\hline \multirow{2}{*}{ Item } & \multicolumn{4}{c}{ Keterangan } \\
\cline { 2 - 5 } & Sangat Puas & Puas & $\begin{array}{c}\text { Cukup } \\
\text { Puas }\end{array}$ & $\begin{array}{c}\text { Kurang } \\
\text { Puas }\end{array}$ & $\begin{array}{c}\text { Tidak } \\
\text { Puas }\end{array}$ \\
\hline $\begin{array}{l}\text { Kebersihan dan kerapian } \\
\text { tempat operasional }\end{array}$ & $12 \%$ & $78 \%$ & $10 \%$ & \\
Penampilan karyawan & $26 \%$ & $74 \%$ & & \\
\hline \multicolumn{1}{c}{ Jumlah } & $\mathbf{1 9 \%}$ & $\mathbf{7 6 \%}$ & $\mathbf{5 \%}$ & \\
\hline
\end{tabular}

Berdasarkan tabel 6 hasil deskriptif dengan perhitungan persentase dari skor faktor penentuan jasa layanan indikator Reliability maka nilainya yang paling besar yaitu $87 \%$ pada kolom "Puas". Nilai yang diperoleh menunjukan pengertian bahwa konsumen merasa puas dengan ketepatan waktu buka dan sopan santun karyawan dari Dealer Suzuki PT. DAS Cabang Pangkalan Bun. Berdasarkan tabel 9 hasil deskriftif dengan perhitungan skor faktor penentu jasa layanan indikator Responsiviness maka nilai yang paling besar yaitu $64 \%$ pada kolom "Puas". Nilai yang diperoleh menunjukan pengertian bahwa konsumen merasa puas dengan kesiapan karyawan untuk menanggapi permintaan konsumen dan pelayanan karyawan dalam menangani keluhan pada Dealer Suzuki PT. DAS Cabang Pangkalan Bun. Berdasarkan tabel 12 hasil deskriptif dengan perhitungan persentase dari skor faktor penentuan jasa layanan indikator Assurance maka nilainya yang paling besar yaitu $61 \%$ pada kolom "Puas". Nilai yang diperoleh menunjukan pengertian bahwa konsumen merasa puas dengan karyawan yang mempunyai pengetahuan dan kemampuan dalam menjalankan tugasnya dan komunikasi yang efektif antara karyawan kepada konsumen dari Dealer Suzuki PT. DAS Cabang Pangkalan Bun. Berdasarkan tabel 15 hasil deskriptif dengan perhitungan persentase dari skor faktor penentuan jasa layanan indikator Empathy maka nilainya yang paling besar yaitu $78 \%$ pada kolom "Puas". Nilai yang diperoleh menunjukan pengertian bahwa konsumen merasa puas dengan Dealer Suzuki PT. DAS Cabang Pangkalan Bun yang memberikan perhatian kepada konsumen secara individual dan memberikan perhatian terhadap kebutuhan dan keperluan konsumen. Berdasarkan tabel 18 hasil deskriptif dengan perhitungan persentase dari skor faktor penentuan jasa layanan indikator Tengible maka nilainya yang paling besar yaitu $76 \%$ pada kolom "Puas". Nilai yang diperoleh menunjukan pengertian bahwa konsumen merasa puas dengan kebersihan dan kerapian tempat operasional dan penampilan karyawan dari Dealer Suzuki PT. DAS Cabang Pangkalan Bun.

\section{PENUTUP}

\section{Kesimpulan}

Berdasarkan hasil analisis maka dapat diambil kesimpulan tentang kepuasan konsumen tentang pelayanan pada Dealer Suzuki PT. DAS Cabang Pangkalan Bun sebagai berikut: Kepuasan konsumen tentang pelayanan jasa pada Dealer Suzuki PT. DAS Cabang Pangkalan Bun pada indikator Keandalan (Reliability) sebesar 87\% pada kolom "Puas", artinya Konsumen merasa puas terhadap ketepatan waktu buka dan kesopan santunan karyawan dari Dealer Suzuki PT. DAS Cabang Pangkalan Bun. Kepuasan konsumen tentang pelayanan jasa pada Dealer Suzuki PT. DAS Cabang Pangkalan Bun pada indikator Daya Tanggap (Responsiviness) sebesar $64 \%$ pada kolom "Puas", artinya konsumen merasa puas terhadap kesiapan karyawan untuk menanggapi permintaan dan pelayanan karyawan dalam 
menangani keluhan pada Dealer Suzuki PT. DAS Cabang Pangkalan Bun. Kepuasan konsumen tentang pelayanan jasa pada Dealer Suzuki PT. DAS Cabang Pangkalan Bun pada indikator Jaminan (Assurance) sebesar $61 \%$ pada kolom "Puas", artinya konsumen merasa puas terhadap pengetahuan serta kemampuan karyawan dalam menjalankan tugas dan komunikasi yang efektif antar karyawan dengan konsumen dari Dealer Suzuki PT. DAS Cabang Pangkalan Bun. Kepuasan konsumen tentang pelayanan jasa pada Dealer Suzuki PT. DAS Cabang Pangkalan Bun pada indikator Empati (Empathy) sebesar 78\% pada kolom puas, artinya konsumen merasa puas terhadap perhatian yang diberikan kepada konsumen secara individual dan perhatian terhadap kebutuhan dan keperluan konsumen dari karyawan pada Dealer Suzuki PT. DAS Cabang Pangkalan Bun. Kepuasan konsumen tentang pelayanan jasa pada Dealer Suzuki PT. DAS Cabang Pangkalan Bun pada indikator Berwujud (Tangible) sebesar $76 \%$ pada kolom puas, artinya konsumen merasa puas terhadap kebersihan serta kerapian tempat operasional dan penampilan karyawan Dealer Suzuki PT. DAS Cabang Pangkalan Bun.

\section{Saran}

Untuk mempertahankan lagi keyakinan dan kepercayaan serta kepuasan konsumen maka pelayanan terhadap konsumen harus ditingkatkan dan diperhatikan secara khusus seperti ketepatan waktu buka, kesiapan karyawan dalam menanggapi permintaan pelanggan, lebih cepat dalam menangani keluhan pelanggan, meningkatkan pengetahuan karyawan, meningkatkan komunikasi antara karyawan dengan konsumen, memberikan perhatian lebih dekat pada konsumen secara individual, memberikan perhatian pada kebutuhan konsumen dan menperhatikan kebersihan serta kerapian tempat operasional DAS Cabang Pangkalan Bun. Pihak Dealer Suzuki PT. DAS Cabang Pangkalan Bun diharapkan lebih peka terhadap keinginan dan kepuasan setiap pelanggan / konsumen agar konsumen tetap memilih jasa pelayanan dari Dealer Suzuki PT. DAS Cabang Pangkalan Bun.

\section{DAFTAR PUSTAKA}

Arikonto S. (2010). Prosedur Penelitian-Suatu Pendekatan Praktik. Jakarta: PT Rineka Cipta. Assauri, Sofjan. (2010). Manajemen Pemasaran. Jakarta: Rajawali Pers.

Gerson, R. (2004). Mengukur Kepuasan Pelanggan. Jakarta: PPM.

Hasibuan, H Malayu S. P. (2008). Manajemen Sumber Daya Manusia Edisi Revisi. Jakarta: PT. Bumi Aksara.

Irianto, Jusuf. (2001). Isu-Isu Strategis Pengembangan Sumber Daya Manusia. Jawa Timur: Insan Cendekia.

Kotler, Philip. (1994). Marketing. Jakarta: Erlangga.

Kotler, Philip. (2010). Kotler on Marketing. Tangerang: KARISMA Publishing Group

Martono, Nanang. (2010). Metodologi Penelitian Kuantitatif Edisi Revisi. Jakarta: PT. GRASINDO PERSADA.

Nasution, M. N. (2004). Manajemen Jasa Terpadu. Bojongkerta, Ciawi Bogor Selatan: Ghalia Indonesia.

Payne, Adrian. (2001). Servis Marketing Pemasaran Jasa. Yogyakarta: And.

Rangkati, Freddy. (1997). Riset Pemasaran. Jakarta: PT. Gramedia Pustaka Utama.

Riduwan. (2009). Pengantar Statistik Pendidikan, Sosial, Ekonomi, Komunikasi dan Bisnis. Bandung: Alfabeta.

Shciffman, leon dan Leslie Lazar Kanuk. (2004). Perilaku Konsumen Edisi ketujuh. Jakarta: PT. INDEKS.

Sugiyono. (1999). Metode Penelitian Bisnis. Bandung: CV. Alfabeta.

Sugiyono. (2011). Metode Penelitian Kuantitatif, Kualitatif dan R\&D. Bandung: CV Alfabeta. 